Nr 3(66), 2020, s. 303-314

https://doi.org/10.12797/Politeja.17.2020.66.21

\author{
Mira MALCZYŃSKA-BIAŁY (D) \\ Uniwersytet Rzeszowski \\ mira19@interia.pl
}

\title{
OCHRONA PRAW KONSUMENTA \\ W POLSKIEJ RZECZYPOSPOLITEJ \\ LUDOWEJ W LATACH 1952-1989
}

ABSTRACT The Protection of Consumer Rights in the Polish People's Republic in 1952-1989

The article, based on the analysis of legal acts and literature on the subject, aims to present the protection of consumer rights in a communist state on the example of the Polish People's Republic. Selected legal regulations in force in 1952-1989 , whose subjects were consumers, were discussed. The article indicates the dangers faced by consumers shopping in the then Polish state. Attention was also paid to the rights of consumers (including warranty) as well as the real threats to their rights resulting from the properties of the centrally planned economy. The last part of the article fulfills the role of conclusion. It contains considerations on the actual safety of consumers who, in the absence of availability of consumer goods, purchased products and services at inflated prices and of reduced quality.

Keywords: consumer, consumer interest, consumer rights, Polish People's Republic

Słowa kluczowe: konsument, interes konsumenta, prawa konsumenta, Polska Rzeczpospolita Ludowa 


\section{UWAGI WSTĘPNE}

O ile kwestia ochrony praw konsumenta na poziomie międzynarodowym jest szeroko opracowana w literaturze przedmiotu, o tyle zauważalny jest brak analiz tego obszaru w państwach Europy Środkowej i Wschodniej przed 1989 r. Podstawowym celem artykułu jest ukazanie ochrony praw konsumenta w Polskiej Rzeczypospolitej Ludowej (PRL). Aby go osiągnąć, wyróżniono oraz przeanalizowano etapy owej ochrony, zaprezentowano jej wybrane aspekty prawne oraz skupiono się na przedstawieniu podstawowych rzeczywistych zagrożeń, z którymi mógł spotkać się ówczesny konsument podczas procesu zakupowego. Opracowanie opiera się na następujących założeniach: po pierwsze, w systemie prawnym PRL zagadnienia ochrony konsumenta zostały włączone do zakresu działań ideologiczno-politycznych. Po drugie, PRL posiadała regulacje prawne mające na celu chronić konsumentów, jednak w ówczesnych realiach życia społeczno-gospodarczego nie spełniały swojej funkcji. W artykule wykorzystano szereg metod charakterystycznych dla nauk o polityce: studium przypadku, analizę instytucjonalno-prawną, analizę historyczną i analizę systemową. Cezura czasowa obejmuje lata 1952-1989 - okres istnienia PRL.

Polska Rzeczpospolita Ludowa jako organizm państwowy została powołana na mocy Konstytucji z dnia 22 lipca 1952 r. ${ }^{1}$ i funkcjonowała do 1989 r. ${ }^{2}$ Regulacje ustawy zasadniczej PRL nie odnosiły się wprost do ochrony konsumentów, zawierały jednak pewne unormowania poświęcone zapewnieniu praw obywatelom jako konsumentom. Fundamentalną gwarancją konstytucyjną w dziedzinie zabezpieczenia konsumpcji dóbr materialnych i niematerialnych była regulacja art. 3 pkt 5 , zgodnie z którą do podstawowych celów PRL należało zabezpieczanie statego wzrostu dobrobytu, zdrowotności i poziomu kulturalnego mas ludowych ${ }^{3}$. Ustawa zasadnicza przyznawała ponadto liczne prawa obywatelskie mające w zamierzeniu służyć zabezpieczeniu interesów konsumenta. Zaliczano do nich: prawo do wypoczynku (art. 59 ust. 1), prawo do ochrony zdrowia oraz pomocy w razie choroby lub niezdolności do pracy (art. 60 ust. 1), prawo do nauki (art. 61 ust. 1) oraz prawo do korzystania ze zdobyczy kultury (art. 81 ust. 1). W rozdziale dotyczącym ustroju społeczno-gospodarczego państwa wymieniano jako główne zadanie planowanej polityki gospodarczej podnoszenie poziomu życiowego mas pracujących (art. 7 ust. 3 ).

Ustrojem gospodarczym w PRL był system centralnie planowany. Zgodnie z art. 7 konstytucji Polska Ludowa, opierając się na uspołecznionych środkach produkcji, wymianie, komunikacji i kredycie, rozwijała życie gospodarcze i kulturalne kraju zgodnie z narodowym planem gospodarczym. Jego podstawą było przyjmowanie

Konstytucja Polskiej Rzeczypospolitej Ludowej uchwalona przez Sejm Ustawodawczy w dniu 22 lipca 1952 r., Dz.U. 1952, nr 33, poz. 232.

2 Zob. Ustawa z dnia 29 grudnia 1989 r. o zmianie Konstytucji Polskiej Rzeczypospolitej Ludowej, Dz.U. 1989, nr 75, poz. 444. Ustawa zmieniła dotychczasową nazwę państwa na „Rzeczpospolitą Polską" (art. 1 pkt 1).

3 Por. S. Soltysiński, Ochrona praw konsumenta, „Państwo i Prawo” 1971, nr 12, s. 891. 
jako obowiązujących pewnych wielkości docelowych, do których dostosowywano wszystkie inne działania planistyczne. Przy konstruowaniu planu posługiwano się stałymi cenami i płacami w celu zbilansowania siły nabywczej z masą towarów i usług nabywanych przez ludność. Jeżeli podczas wykonywania planu występował niedobór towarów, wprowadzano limitację dóbr podstawowych, m.in. za pomocą systemów kartkowych ${ }^{4}$. Dokładne określenie zapotrzebowania gospodarki na poszczególne produkty, urządzenia czy surowce było niemożliwe, dlatego brak konkretnego detalu czy podzespołu powodował niemożność realizowania zadań planowych w wielu przedsiębiorstwach ${ }^{5}$.

Pomimo, iż odgórnie narzucony plan zawierał zarówno konkretne wytyczne jakościowe jak i ilościowe, szczególne znaczenie przywiązywano do ilości wytwarzanych dóbr materialnych. Niższy poziom jakości dóbr, często przestarzałych technologicznie, nie obniżał ich zbytu. Związane to było z zapewnieniem przez państwo odbioru całej wykonanej oraz często ponadplanowej produkcji .

W gospodarce centralnie planowanej ochrona konsumentów polegała przede wszystkim na ochronie przed działaniami przestępczymi w sferze obrotu towarowego. Zaliczano do nich sprzedaż konsumentom towarów o niższej jakości po wyższej niż obowiązującej cenie oraz w mniejszej ilości ${ }^{7}$.

Polska Rzeczpospolita Ludowa posiadała regulacje prawne mające na celu ochronę konsumentów, ale w ówczesnych realiach życia społeczno-gospodarczego nie do końca spełniały swoją funkcję. Uważano, że niektóre zagrożenia dla konsumentów wynikają ze sprzeczności gospodarki kapitalistycznej. Uspołecznienie gospodarki oraz poddanie jej zasadzie planowania miało sprzyjać realizacji zamierzonej polityki społeczno-gospodarczej oraz gwarantować bezpieczeństwo konsumentom ${ }^{9}$. Zadaniem tej polityki była m.in. działalność edukacyjna poprzez propagowanie zasad rozsądnego prowadzenia gospodarstwa domowego; aspekt edukacji konsumenckiej polegał na zastąpieniu subiektywnych motywów postępowania racjonalnością, ekonomicznością oraz świadomością wyboru ${ }^{10}$.

\footnotetext{
A. Jezierski, C. Leszczyńska, Historia gospodarcza Polski, Warszawa 2002, s. 493.

Z. Landau, W. Roszkowski, Polityka gospodarcza II RP i PRL, Warszawa 1995, s. 92.

6 Tamże, s. 93.
}

7 B. Kołodziejek, Interpretacja zjawiska naruszania interesów konsumenta w warunkach gospodarki planowej, [w:] Interesy konsumentów a dziatalność handlu. Materiaty z konferencji Warszawa-Jadwisin 29-30 X 1973, Warszawa 1975, s. 56, 59.

8 J. Drągalski, J. Kwaśniewski, (Nie)realny socjalizm, Warszawa 1992, s. 149.

9 E. Łętowska, Ksztattowanie się odrębności obrotu mieszanego, [w:] Tendencje rozwoju prawa cywilnego, red. E. Łętowska, Wroctaw 1983, s. 400.

10 B. Kowrygo, Rola i zadania spótdzielczości w zakresie edukacji konsumenta, „Spółdzielczy Kwartalnik Naukowy" 1985, nr 1, s. 39. Por. K. Wójcik, Edukacja konsumenta jako czynnik ksztattowania jakości życia, Warszawa 1978, s. 134. 


\section{ETAPY ROZWOJU OCHRONY PRAW KONSUMENTA W POLSKIEJ RZECZPOSPOLITEJ LUDOWEJ}

Rozwój ochrony prawnej konsumenta w PRL można podzielić, za Czesławą Żuławską $^{11}$, na dwa etapy. Pierwszy etap rozwoju, do końca lat 60 . XX w., determinowany był przez ideologię totalitarną, według której państwo kierowało życiem społecznym i gospodarczym. Nadrzędnym celem gospodarczym był wówczas rozwój przemysłu ciężkiego, jego rozbudowa, zaopatrzenie i obsługa. Zgodnie z założeniami systemu gospodarki nakazowo-rozdzielczej obywatel stanowił element składowy masy pracującej, wykonującej określone zadanie planowe. Konsument nie mógł samodzielnie decydować o swoich potrzebach oraz o sposobie i poziomie ich zaspokajania. To państwo określało i realizowało te potrzeby, m.in. z „funduszu spożycia zbiorowego”, do którego zaliczano system tanich mieszkań, wczasów pracowniczych, system zaopatrywania przez rozdzielnictwo, przywileje grupowe i indywidualne oraz organizację żywienia w stołówkach pracowniczych i szkolnych ${ }^{12}$. System przywilejów i rozdzielnictwa demoralizował obie strony obrotu gospodarczego oraz powodował zanik odpowiedzialności konsumenta za swój wybór. Wywoływało to powszechną bierność konsumentów w podejmowaniu prób ochrony prywatnych interesów wobec przedsiębiorstwa czy mienia państwowego ${ }^{13}$.

Planowy charakter centralnie zarządzanej, uspołecznionej gospodarki skupiał się na tzw. ochronie kreatywnej, czyli władczych administracyjno-prawnych formach ochrony konsumentów. Należały do nich rozwinięty system karny w stosunku do osób dopuszczających się przestępczości gospodarczej ${ }^{14}$, normalizacja techniczna wpływająca na jakość produkcji oraz funkcjonowanie służb kontroli ${ }^{15}$.

Brak możliwości zaspokojenia potrzeb konsumenckich przez funkcjonujące placówki usługowe i handlowe sprawiał, że na szeroką skalę rozwijał się handel nieoficjalny, polegający na „załatwianiu” pożądanego dobra konsumenckiego. Szerzył się również „czarnorynkowy” handel wymienny, zgodnie z zasadą towar za towar ${ }^{16}$. Tym patologicznym problemom ówczesnego życia społecznego towarzyszyły nadużycia o charakterze korupcyjnym ${ }^{17}$.

Na bezpieczeństwo i ochronę praw konsumenta wpływały okoliczności, w jakich nabywano świadczenie czy dobro materialne. Powszechnym zjawiskiem było naruszanie

11 C. Żuławska, O prawach konsumenta w okresie przemian, „Roczniki Nauk Społecznych. Nauki Społeczno-Ekonomiczne" 1994-1995, t. 22-23, z. 1, s. 377.

13 W. Wasiak, Determinanty i podstawy prawne ochrony interesów konsumentów w Polsce, „Prace Naukowe Akademii Ekonomicznej we Wrocławiu. Rynek i konsumpcja” 1985, nr 289, s. 103.

14 Zob. Ustawa z dnia 19 kwietnia 1969 r. - Kodeks karny, Dz.U. 1969, nr 13, poz. 94 z późn. zm. (art. 224 ust. 1 , art. 225 ust. 1, 2).

15

16 W. Wasiak, Determinanty i podstawy..., s. 103.

17 Zob. D. Jarosz, M. Pasztor, Afera mięsna. Fakty i konteksty, Toruń 2004, s. 15-16. 
interesów konsumenta poprzez dotkliwe i upokarzające lekceważenie go ${ }^{18}$. Konsument nie mógł wówczas uzyskać satysfakcjonującej pozycji na rynku. Miały na to wpływ nie tylko niemożność ilościowego i jakościowego zaspokojenia dóbr i usług, lecz także obojętny, a niekiedy wręcz arogancki stosunek sprzedawców i usługodawców do klienta, wynikający z braku ich zainteresowania wynikami działalności oraz braku kultury zawodowej i osobistej personelu placówek usługowych i handlowych. Konsument zazwyczaj w takiej sytuacji i tak nie rezygnował z nabycia towaru czy usługi, bo była deficytowa. Nagminność tych zjawisk, szczególnie w pierwszej połowie lat 50., oraz pewnego rodzaju zobojętnienie ogółu społeczeństwa na ten stan rzeczy spowodowały niemal całkowitą rezygnację konsumentów z przysługujących im praw ${ }^{19}$.

Tworzone w tym okresie regulacje prawne dotyczące jakości dóbr i usług były ukierunkowane przede wszystkim na stworzenie różnorodnych form oddziaływania na producentów i dystrybutorów, a nie na ochronę bezpieczeństwa i interesów konsumenta indywidualnego. Organizacja kontroli jakości wyrobów konsumenckich oraz obowiązek umieszczania znaków weryfikacyjnych na artykułach dopuszczonych do obrotu towarowego znalazły odzwierciedlenie w licznych aktach prawnych. Stanowity one impuls do rozwoju ustawodawstwa w tym zakresie oraz do tworzenia infrastruktury kontrolno-organizacyjnej.

Jednym z pierwszych unormowań w sprawie jakości produkcji obowiązującym w PRL była Uchwała Komitetu Ekonomicznego Rady Ministrów z dnia 12 maja $1950 \mathrm{r}^{20}$ Kolejny akt prawny, który miał zapewniać właściwą jakość towarów, to Dekret z dnia 4 marca 1953 r. o normach i o Polskim Komitecie Normalizacyjnym ${ }^{21}$. Pierwszą regulacją prawną dotyczącą bezpośrednio bezpieczeństwa i ochrony interesów konsumenta indywidualnego była zaś Uchwała nr 355 Rady Ministrów z dnia 19 września 1958 r. w sprawie zapewnienia właściwej jakości towarów przeznaczonych na zaopatrzenie ludności ${ }^{22}$. W rozdziale pierwszym określała ona stosunki między dostawcami a odbiorcami w zakresie jakości towarów oraz zgłaszania reklamacji z tego tytułu. Ochronie interesu konsumenta miała służyć ponadto działalność wyspecjalizowanych organów kontroli, do których zaliczano przede wszystkim: Państwową Inspekcję Handlową, Państwową Inspekcję Sanitarną, Inspekcję Nasienną, Polski Komitet Normalizacyjny, Naczelną Izbę Kontroli oraz organy prokuratury ${ }^{23}$.

W omawianym okresie głównym instrumentem prawnym służącym ochronie interesów konsumentów dóbr materialnych podczas procesu zakupowego był Kodeks

18 W. Wasiak, Determinanty i podstawy..., s. 115.

19 C. Żuławska, Ochrona konsumenta w reformowanej gospodarce, „Spółdzielczy Kwartalnik Naukowy” 1985, nr 3, s. 104.

20 Uchwata Komitetu Ekonomicznego Rady Ministrów z dnia 12 maja 1950 r. w sprawie jakości produkcji, M.P. 1950, nr 65, poz. 765 .

${ }^{21}$ Dekret $z$ dnia 4 marca 1953 r. o normach i o Polskim Komitecie Normalizacyjnym, Dz.U. 1953, nr 15, poz. 61.

22 Uchwata nr 355 Rady Ministrów z dnia 19 września 1958 r. w sprawie zapewnienia wtaściwej jakości towarów przeznaczonych na zaopatrzenie ludności, M.P. 1958, nr 77, poz. 450.

23 S. Soltysiński, Ochrona praw konsumenta..., s. 902. 
cywilny (k.c. $)^{24}$, ustalający zasady rękojmi za wady fizyczne oraz gwarancjii ${ }^{25}$. Zgodnie $\mathrm{z}$ art. 556 ust. 1 k.c. sprzedawca był odpowiedzialny wobec kupującego, gdy sprzedawana rzecz posiadała wadę zmniejszającą jej wartość lub użyteczność ze względu na cel określony w umowie bądź wynikający z okoliczności i przeznaczenia rzeczy. Sprzedawca był ponadto odpowiedzialny, gdy towar nie miał właściwości, o których istnieniu zapewnił kupującego, albo gdy rzecz została wydana w stanie niezupełnym. Co do zasady konsument mógł odstąpić od umowy lub żądać obniżenia ceny, jeżeli sprzedana rzecz miała wady (art. 560 ust. 1). Istotnym ograniczeniem praw konsumenta w zakresie odstąpienia od umowy była jednak regulacja art. 560 ust. 1, zgodnie z którą nabywca nie mógł skorzystać z prawa odstąpienia od umowy lub żądania obniżenia ceny, jeżeli sprzedawca oświadczył gotowość natychmiastowej wymiany rzeczy wadliwej na wolną od wad lub niezwłoczne usunięcie wady. W praktyce od złożenia takiego oświadczenia woli sprzedawcy do chwili efektywnego zaspokojenia uprawnień nabywcy upływało często wiele miesięcy. Wiązało się to z brakiem przygotowania zarówno sprzedawców, jak i producentów do dokonywania napraw ${ }^{26}$.

Innym instrumentem, w założeniu mającym chronić prawa konsumenta, była instytucja gwarancji. Kładła ona nacisk na uprawnienia nabywcy w zakresie żądania naprawy rzeczy lub wymianę rzeczy na nową. Stosowana była wówczas, gdy sprzedawca zapewnił kupującego na piśmie o jakości sprzedanej rzeczy. W przypadku ujawnienia wady fizycznej zobowiązywał się w określonym w dokumencie terminie do jej usunięcia lub do dostarczenia rzeczy wolnej od wad (art. 577 ust. 1). Powyższa regulacja przyznawała wybór formy spełnienia świadczenia sprzedawcy. W praktyce dostarczenie rzeczy wolnej od wad następowało po kilkakrotnych bezskutecznych naprawach, a okres oczekiwania na wydanie przedmiotu zastępczego był - w szczególności w przypadku dóbr trwałego użytku - bardzo długi. Artykuł 579 ograniczał prawa konsumenta do odstąpienia od umowy. Zgodnie z nim kupujący, który otrzymał gwarancję, mógł skorzystać z uprawnień z tytułu rękojmi za wady fizyczne rzeczy dopiero wówczas, gdy sprzedawca we właściwym czasie nie wywiązał się z obowiązków wynikających z gwarancji. W rzeczywistości regulacje dotyczące rękojmi w postaci możliwości odstąpienia od umowy były iluzją: większość towarów trwałego użytku była trudno dostępna, dlatego praktycznie żaden z nabywców nie był zainteresowany zwróceniem wadliwego towaru ${ }^{27}$.

Kolejny etap rozwoju praw konsumenta w PRL, obejmujący lata 70. i 80. XX w., był związany z załamaniem się koncepcji stałego planowego rozwoju gospodarki socjalistycznej. W drugiej połowie lat 70., w związku z polityką państwa opartą na podwyższaniu płac nominalnych przy zachowaniu w miarę stabilnych cen, doszło do znacznego wzrostu popytu przy jednoczesnym rosnącym zadłużeniu państwa. Polska utraciła

\footnotetext{
Ustawa z dnia 23 kwietnia 1964 r. - Kodeks cywilny, Dz.U. 1964, nr 16, poz. 93 z późn. zm.

E. Łętowska, Prawo umów konsumenckich..., s. 5.

26 S. Soltysiński, Ochrona praw konsumenta..., s. 893.

27 J. Lewandowski, A. Wiśniewski, Skuteczność ochrony interesów konsumenta w świetle przepisów prawa, [w: Interesy konsumentów a dziatalność handlu..., s. 303.
} 
wiarygodność kredytową na arenie międzynarodowej, co wpłynęło na zmniejszenie importu większości artykułów rynkowych. Niedostatek towarów i usług spowodował wzrost cen w obrocie detalicznym. Pacyfikując falę strajków, władza przyznała protestującym podwyżki płac oraz liczne dodatki do wynagrodzenia, m.in. w formie dodatków rodzinnych ${ }^{28}$. Na rynku doszło więc do wzrostu wysokości dochodów społeczeństwa przy jednoczesnym braku dostępności towarów i usług. Towarzyszyły temu patologiczne zjawiska rynkowe: wykupywano rzadkie artykuły i odsprzedawano je po znacznie wyższych cenach, poza siecią handlu państwowego i spółdzielczego ${ }^{29}$. Rozwinął się też system łapówkarski wśród pracowników handlu w zamian za umożliwienie kupna jakiegoś towaru.

Obowiązujące wówczas regulacje Kodeksu wykroczeń (k.w. $)^{30}$ miały w założeniu przeciwdziałać niezdrowym sytuacjom rynkowym. W rozdz. XV kodeks wprowadzał kategorię przestępstw przeciwko interesom konsumentów. Znalazły się w nim także regulacje dotyczące wymiaru kar w stosunku do zatrudnionych w przedsiębiorstwach handlu detalicznego lub prowadzących je osób zbywających towar w celu odsprzedaży z zyskiem oraz osób nabywających w celu odsprzedaży z zyskiem biletów wstępu na imprezy artystyczne, sportowe i rozrywkowe. Naruszające interesy konsumentów i tym samym zagrożone karą były też sprzedaż towaru lub świadczenie usługi oszukującej nabywcę co do ilości, wagi, miary, gatunku, rodzaju i ceny (art. 134 ust. 1). Powyższe nadużycia podlegały karze aresztu, ograniczenia wolności lub grzywny. Osoby zajmujące się sprzedażą towarów w przedsiębiorstwie handlu detalicznego ukrywające przed nabywcą towar przeznaczony do sprzedaży lub z premedytacją i bez uzasadnionych przyczyn odmawiające sprzedaży także podlegały karze grzywny (art. 135).

Brak towarów stał się przyczyną wprowadzenia w 1980 r. kartek na artykuły spożywcze, takie jak mąka, cukier, produkty zbożowe, tłuszcze i czekolada, jak również papierosy i alkohol ${ }^{31}$. W okresie kryzysu lat 80 . doszło do tego, że oczekujący w długich kolejkach konsumenci wykupywali wszystkie towary dostarczone do sklepów, często nie zwracając uwagi na ich przydatność. Sytuacja gospodarcza w Polsce w tamtych latach charakteryzowała się brakiem podstawowych dóbr konsumpcyjnych przy jednoczesnej malejącej wartości pieniądza. Konieczne więc było odejście od nieefektywnego systemu ekonomicznego oraz stworzenie nowego ${ }^{32}$. Realizację tych zadań miała zapewnić reforma gospodarcza.

Jesienią 1980 r. Biuro Polityczne Komitetu Centralnego Polskiej Zjednoczonej Partii Robotniczej (PZPR) powołało Komisję ds. Reformy Gospodarczej. W połowie

28 Z. Landau, W. Roszkowski, Polityka gospodarcza..., s. 131-133.

29 Rozwijał się „drugi obieg w gospodarce planowanej”, zdefiniowany jako wszelkie rodzaje działalności gospodarczej prowadzone poza legalnie funkcjonującym systemem. Szerzej na ten temat zob. W. Ślaga, Drugi obieg gospodarki w Polsce-potrzeba nowego spojrzenia, [w:] Ekonomiczne uwarunkowania ksztattowania się sytuacji politycznej w Polsce w 1989 roku, red. J. Hausner, Kraków 1992, s. 197-204.

30 Ustawa z dnia 20 maja 1971 r. - Kodeks wykroczeń, Dz.U. 1971, nr 12, poz. 114 z późn. zm.

31 Z. Landau, W. Roszkowski, Polityka gospodarcza..., s. 134.

32 C. Żuławska, Obrót z udziatem konsumenta. Ochrona prawna, Wrocław 1987, s. 44. Szerzej o sytuacji na rynku konsumpcyjnym w latach 80. zob. Polska 5 lat po sierpniu. Raport, Londyn 1986, s. 106-107. 
1981 r. przygotowała ona dokument Kierunki reformy gospodarczej33 , stanowiący wizję zreformowanego systemu gospodarczego ${ }^{34}$. Niektóre zawarte w nim regulacje były korzystne dla konsumentów, stanowiąc swoistą podstawę dla rozwoju ich praw. Przede wszystkim zgodnie z pkt. 22 dokumentu miały zostać stworzone podstawy prawno-organizacyjne ochrony konsumenta. Społeczne ruchy konsumenckie zyskałyby możliwość oddziaływania na decyzje przedsiębiorstw oraz organów administracji państwowej. Rozwinięcie systemu i form ochrony interesów konsumenta zostałoby zadaniem Ministerstwa Handlu Wewnętrznego i Usług ${ }^{35}$. W rozdz. III dokumentu, dotyczącym podstawowych zasad funkcjonowania gospodarki, wskazano na konieczność uspołecznienia planowania, czyli udziału społeczeństwa, w tym konsumentów, w wyrażaniu woli co do hierarchii potrzeb materialnych, socjalnych i kulturalnych (pkt 32).

Ochronę konsumenta gwarantowała również Ustawa z dnia 26 lutego 1982 r. o cenach $^{36}$. Kontrola cen ze strony organów państwa obejmowała segmenty rynku zaopatrzeniowego oraz dóbr konsumpcyjnych. Nie prowadziła jednak do zbilansowania popytu z ograniczoną podażą ${ }^{37}$. Ustawa wskazywała, iż w miejscach sprzedaży detalicznej powinny znajdować się proste i niebudzące wątpliwości informacje na temat cen, ich wysokości i rodzaju (art. 15).

W latach 1981-1985, wraz z załamaniem się gospodarki państwowej, następował wzrost sektora prywatnego i liczby prywatnych przedsiębiorstw ${ }^{38}$. Dla konsumentów wiązało się to $\mathrm{z}$ łatwiejszym dostępem do potrzebnych produktów oraz możliwością większego wyboru. Na podstawie Ustawy z dnia 6 lipca 1982 r. o zasadach prowadzenia na terytorium Polskiej Rzeczypospolitej Ludowej działalności gospodarczej w zakresie drobnej wytwórczości przez zagraniczne osoby prawne i fizyczne ${ }^{39}$ powstał nowy rodzaj przedsiębiorstw z udziałem kapitału zagranicznego.

W drugiej połowie lat 80 . XX w. podejmowano w Polsce próby przebudowy gospodarki. Służyć temu miał tzw. drugi etap reformy gospodarczej, zapoczątkowany przeprowadzeniem 29 listopada 1987 r. ogólnopaństwowego referendum. W jego konsekwencji projekt rządowych reform został odrzucony ${ }^{40}$. Kolejnym działaniem podjętym

33 Kierunki reformy gospodarczej. Projekt. Projekty ustaw - o przedsiębiorstwach państwowych, o samorzadzie zatogi przedsiębiorstwa państwowego, Warszawa 1981, s. 65-67.

34 Szerzej na temat przemian systemowych i polityce gospodarczej w latach 1981-1989 zob. J. Kaliński, Z. Landau, Gospodarka Polski w XX wieku, Warszawa 2003, s. 338-345.

35 Zob. Kierunki reformy gospodarczej..., załącznik nr 1, rozdz. II, pkt 5.

36 Ustawa z dnia 26 lutego 1982 r. o cenach, Dz.U. 1982, nr 7, poz. 52 z późn. zm.

37 W. Welfe, Zasady makromodelowania gospodarki okresu transformacji. Gtówne postulaty teoretyczne, [w:] Gospodarka polski w okresie transformacji. Zasady modelowania ekonometrycznego, red. tenże, Warszawa 2000, s. 9.

38 L. Habuda, Od PRL do Trzeciej Rzeczypospolitej i dalej... Liberalna demokracja i wolnorynkowa gospodarka. Dlaczego i jakie?, Torun 2007, s. 68.

39 Ustawa z dnia 6 lipca 1982 r. o zasadach prowadzenia na terytorium Polskiej Rzeczypospolitej Ludowej dziatalności gospodarczej w zakresie drobnej wytwórczości przez zagraniczne osoby prawne i fizyczne, Dz.U. 1982, nr 19, poz. 146.

$40 \quad$ L. Habuda, Od PRL do Trzeciej Rzeczypospolitej..., s. 71. 
w celu uzdrowienia gospodarki było wprowadzenie zasady wolności gospodarczej ${ }^{41}$. Zgodnie z ustawą podejmowanie i prowadzenie działalności gospodarczej ${ }^{42}$ było wolne i dozwolone każdemu na równych prawach (art. 1). Do podjęcia działalności gospodarczej konieczne było zgłoszenie jej do ewidencji gospodarczej (art. 8), natomiast zgłoszenia nie wymagała działalność stanowiąca dodatkowe źródło dochodu dla osoby fizycznej (art. 9 ust. 1).

\section{UWAGI KOŃCOWE}

Ochrona konsumentów w gospodarce krajów Europy Środkowej i Wschodniej przybierała zdecydowanie inny wymiar niż w kapitalistycznych państwach Europy Zachodniej. Gospodarka wolnorynkowa tworzyła całkiem inne problemy oraz zagrożenia dla konsumentów niż gospodarka centralnie planowana. Wolny rynek, obfitujący w różnorodność towarów konsumpcyjnych oraz brak monopolistycznych przedsiębiorstw, wykształcił niebezpieczne dla konsumentów zjawiska nieuczciwych praktyk handlowych w postaci agresywnych lub wprowadzających w błąd działań przedsiębiorców ${ }^{43}$.

W systemie prawnym PRL zagadnienia ochrony konsumenta zostały włączone w zakres działań ideologiczno-politycznych. Przyjęto zasadę, że sprawy ochrony konsumentów powinny być rozwiązywane przez PZPR i struktury administracyjne socjalistycznego państwa. Nakazowy system gospodarki centralnie sterowanej nie uwzględniał istnienia konkurencji wśród podmiotów podaży dóbr i usług ani możliwości wyboru towarów spośród różnorodnej oferty handlowej. Zakładał natomiast trwałą przewagę popytu nad podażą towarów konsumpcyjnych. Niewielkie zróżnicowanie oferty rynkowej, standardowa niska jakość produktów i nagminne niedobory dóbr konsumpcyjnych sprawiały, że nabywcy, ponaglani pilnością zaspokojenia potrzeb bytowych, przeważnie rezygnowali ze stawiania wymagań jakościowych, jednocześnie tolerując nieuczciwość i oszustwa podmiotów związanych z dystrybucją dóbr i usług ${ }^{44}$.

Zakres prawnej ochrony konsumenta indywidualnego jako strony stosunku umownego z uspołecznionym usługodawcą był więc bardzo niski. Miały na to wpływ zarówno sytuacja ekonomiczna, podażowa oraz dystrybucyjna, jak i silnie akcentowana w latach 50. XX w. zasada dominacji interesu społecznego nad interesem jednostki. Uwidaczniało się to w sposobie rozstrzygania sporów między obywatelem a jednostką

41 Ustawa z dnia 23 grudnia 1988 r. o dziatalności gospodarczej, Dz.U. 1988, nr 41, poz. 324 z późn. zm.

42 Działalnością gospodarczą w rozumieniu ustawy była działalność wytwórcza, budowlana, handlowa i usługowa prowadzona w celach zarobkowych i na własny rachunek podmiotu (art. 2 ust. 1).

43 Zob. M. Malczyńska-Biały, Normalizacja europejska a bezpieczeństwo produktów konsumenckich, [w:] Wspótczesna polityka bezpieczeństwa - aspekty militarne i spoteczno-gospodarcze, red. M. Delong, M. Malczyńska-Biały, Rzeszów 2018, s. 66-73.

44 G. Światowy, Ochrona konsumenta w procesie urynkowienia gospodarki polskiej i jej integracji z Unia Europejska, [w:] Socjoekonomiczna i prawna sytuacja konsumentów wobliczu integracji z Unią Europejska, red. K. Gutkowska, I. Ozimek, Warszawa 1998, s. 131. 
uspołecznioną - na korzyść tej drugiej ${ }^{45}$. W latach 80 . XX w. proces wdrażania reformy gospodarczej przypadł na okres głębokiego kryzysu uwidaczniającego się brakiem dóbr oraz zjawiskami inflacyjnymi. Powodowało to poważne zagrożenie interesów konsumentów, którzy wobec braku dostępności dóbr konsumpcyjnych nabywali produkty i usługi po zawyżonych cenach oraz o obniżonej jakości. Regulacje dotyczące przestępstw przeciwko konsumentom w założeniu miały chronić ich interesy, jednak przez represyjny charakter nie spełniały swojej funkcji. W ówczesnych realiach ich znaczenie i efektywność ulegały degradacji ${ }^{46}$.

Pozytywnym zjawiskiem w omawianym okresie PRL było dążenie społeczeństwa do upodmiotowienia ochrony konsumenta w ramach tworzonego ruchu konsumenckiego $^{47}$. Stopniowo zmieniało się postrzeganie relacji państwo-obywatel. Zaczęto zwracać uwagę na powinności państwa względem obywateli, m.in. w zakresie zapewnienia miejsca pracy, mieszkania, wczasów czy stypendiów. Ogromne deficyty rynkowe podstawowych dóbr oraz niska jakość produkcji utrudniały jednak rozwój działań prokonsumenckich. Pierwszy rządowy program polityki konsumenckiej państwa został sformułowany dopiero w 1998 r., już w innych realiach społeczno-gospodarczych ${ }^{48}$.

\section{BIBLIOGRAFIA}

Dekret $z$ dnia 4 marca 1953 r. o normach i o Polskim Komitecie Normalizacyjnym, Dz.U. 1953, nr 15, poz. 61.

Drągalski J., Kwaśniewski J., (Nie)realny socjalizm, Warszawa 1992.

Habuda L., Od PRL do Trzeciej Rzeczypospolitej i dalej... Liberalna demokracja i wolnorynkowa gospodarka. Dlaczego i jakie?, Toruń 2007.

Jarosz D., Pasztor M., Afera mięsna. Fakty i konteksty, Toruń 2004.

Jezierski A., Leszczyńska C., Historia gospodarcza Polski, Warszawa 2002.

Kaliński J., Landau Z., Gospodarka Polski w XX wieku, Warszawa 2003.

Kierunki reformy gospodarczej. Projekt. Projekty ustaw - o przedsiębiorstwach pansstwowych, o samorzadzie zatogi przedsiębiorstwa państwowego, Warszawa 1981.

Kołodziejek B., Interpretacja zjawiska naruszania interesów konsumenta w warunkach gospodarki planowej, [w:] Interesy konsumentów a dziatalność handlu. Materiaty z konferencji Warszawa-Jadwisin 29-30 X 1973, Warszawa 1975.

Konstytucja Polskiej Rzeczypospolitej Ludowej uchwalona przez Sejm Ustawodawczy w dniu 22 lipca 1952 r., Dz.U. 1952, nr 33, poz. 232.

45 W. Wasiak, Determinanty i podstawy prawne..., s. 116.

46 C. Żuławska, Ochrona konsumenta w reformowanej gospodarce..., s. 42.

47 M. Malczyńska-Biały, Wolność zrzeszania się na przyktadzie organizacji konsumenckich w Polsce, [w:] Wolność i odpowiedzialność. Wymiar ekonomiczny, spoteczny i polityczny, red. J. Osiński, Warszawa 2009, s. 61-68.

48 M. Malczyńska-Biały, Consumer Policy in Poland's Process of Accession to the European Union, „Rocznik Integracji Europejskiej” 2018, nr 12, s. 333-341. 
Kowalski J., Z zagadnień teorii demokracji socjalistycznej, [w:] Państwo, naród, demokracja socjalistyczna w PRL, red. J. Kowalski, L. Lisiakiewicz, Warszawa 1970.

Kowrygo B., Rola i zadania spótdzielczości w zakresie edukacji konsumenta, „Spółdzielczy Kwartalnik Naukowy" 1985, nr 1.

Landau Z., Roszkowski W., Polityka gospodarcza II RP i PRL, Warszawa 1995.

Lewandowski J., Wiśniewski A., Skuteczność ochrony interesów konsumenta w świetle przepisów prawa, [w:] Interesy konsumentów a dziatalność handlu. Materiaty z konferencji WarszawaJadwisin 29-30 X 1973, Warszawa 1975.

Łętowska E., Ksztattowanie się odrębności obrotu mieszanego, [w:] Tendencje rozwoju prawa cywilnego, red. E. Łętowska, Wrocław 1983.

Malczyńska-Biały M., Consumer Policy in Poland's Process of Accession to the European Union, „Rocznik Integracji Europejskiej” 2018, nr 12, https://doi.org/10.14746/rie.2018.12.23.

Malczyńska-Biały M., Normalizacja europejska a bezpieczeństwo produktów konsumenckich, [w:] Wspótczesna polityka bezpieczeństwa - aspekty militarne i spoteczno-gospodarcze, red. M. Delong, M. Malczyńska-Biały, Rzeszów 2018.

Malczyńska-Biały M., Wolność zrzeszania się na przyktadzie organizacji konsumenckich $w$ Polsce, [w:] Wolność i odpowiedzialność. Wymiar ekonomiczny, spoteczny i polityczny, red. J. Osiński, Warszawa 2009.

Polska 5 lat po sierpniu. Raport, Londyn 1986.

Sołtysiński S., Ochrona praw konsumenta, „Państwo i Prawo” 1971, nr 12.

Szymczak J., Opakowanie a ochrona interesów konsumenta, [w:] Interesy konsumentów a dziatalność handlu. Materiaty z konferencji Warszawa-Jadwisin 29-30 X 1973, Warszawa 1975.

Ślaga W., Drugi obieg gospodarki w Polsce - potrzeba nowego spojrzenia, [w:] Ekonomiczne uwarunkowania ksztattowania się sytuacji politycznej w Polsce w 1989 roku. Raport syntetyczny i opracowania studialne, red. J. Hausner, Kraków 1992.

Światowy G., Ochrona konsumenta w procesie urynkowienia gospodarki polskiej i jej integracji $z$ Unia Europejska, [w:] Socjoekonomiczna i prawna sytuacja konsumentów w Polsce w obliczu integracji z Unia Europejska. Międzynarodowa konferencja naukowa, Warszawa, 15-16.10.1998, red. K. Gutkowska, I. Ozimek, Warszawa 1998.

Uchwata Komitetu Ekonomicznego Rady Ministrów z dnia 12 maja 1950 r. w sprawie jakości produkcji, M.P. 1950, nr 65, poz. 765.

Uchwata nr 355 Rady Ministrów z dnia 19 września 1958 r. w sprawie zapewnienia wtaściwej jakości towarów przeznaczonych na zaopatrzenie ludności, M.P. 1958, nr 77, poz. 450.

Ustawa z dnia 23 kwietnia 1964 r. - Kodeks cywilny, Dz.U. 1964, nr 16, poz. 93 z późn. zm.

Ustawa z dnia 19 kwietnia 1969 r. - Kodeks karny, Dz.U. 1969, nr 13, poz. 94 z późn. zm.

Ustawa z dnia 20 maja 1971 r. - Kodeks wykroczeń, Dz.U. 1971, nr 12, poz. 114 z późn. zm.

Ustawa z dnia 26 lutego 1982 r. o cenach, Dz.U. 1982, nr 7, poz. 52 z późn. zm.

Ustawa z dnia 6 lipca 1982 r. o zasadach prowadzenia na terytorium Polskiej Rzeczypospolitej Ludowej dziatalności gospodarczej w zakresie drobnej wytwórczości przez zagraniczne osoby prawne i fizyczne, Dz.U. 1982, nr 19, poz. 146.

Ustawa z dnia 23 grudnia 1988 r. o dziatalności gospodarczej, Dz.U. 1988, nr 41, poz. 324 $\mathrm{z}$ późn. $\mathrm{zm}$. 
Ustawa z dnia 24 lutego 1989 r. o niektórych warunkach konsolidacji gospodarki narodowej oraz o zmianie niektórych ustaw, Dz.U. 1989, nr 10, poz. 57.

Ustawa z dnia 29 grudnia 1989 r. o zmianie Konstytucji Polskiej Rzeczypospolitej Ludowej, Dz.U. 1989, nr 75, poz. 444.

Wasiak W., Determinanty i podstawy prawne ochrony interesów konsumenta $w$ Polsce, „Prace Naukowe Akademii Ekonomicznej we Wrocławiu. Rynek i konsumpcja” 1985, nr 289.

Welfe W., Zasady makromodelowania gospodarki okresu transformacji. Gtówne postulaty teoretyczne, [w:] Gospodarka polski w okresie transformacji. Zasady modelowania ekonometrycznego, red. A. Welfe, Warszawa 2000.

Wójcik K., Edukacja konsumenta jako czynnik ksztattowania jakości życia, Warszawa 1978.

Żuławska C., O prawach konsumenta w okresie przemian, „Roczniki Nauk Społecznych. Nauki Społeczno-Ekonomiczne" 1994-1995, t. 22-23, z. 1.

Żuławska C., Ochrona konsumenta w reformowanej gospodarce, „Spółdzielczy Kwartalnik Naukowy” 1985, nr 3.

Żuławska C., Obrót z udziatem konsumenta. Ochrona prawna, Wrocław 1987.

Dr Mira MALCZYŃSKA-BIAŁY - adiunkt w Instytucie Nauk o Polityce Uniwersytetu Rzeszowskiego. Jej zainteresowania badawcze koncentrują się wokół polityki konsumenckiej i praw konsumenta w Unii Europejskiej i Polsce oraz polityki gospodarczej. 